\title{
KONSTRUKSI REGULASI PENYIARAN DI ERA KONVERGENSI
}

\author{
Noneng Sumiaty \\ Balai Pengkajian dan Pengembangan Komunikasi dan Informatika Bandung \\ Jl. Pajajaran No. 88 Bandung 40173, Fax. (022) 6021740 \\ Naskah diterima tanggal 2 Oktober 2012, disetujui tanggal 22 November 2012

\begin{abstract}
THE CONSTRUCTION OF THE REGULATION OF BROADCASTING IN THE ERA OF CONVERGENCE
\end{abstract}

\begin{abstract}
This study discusses the construction of the regulation of Broadcasting by The Broadcasting Act No. 32 of 2002 in the era of convergence which includes articles that is considered to be nolonger compatible with the development of Information and Communication Technology (ICT). The paradigm used in this study is a constructivism paradigm. While the approach is qualitative approach. For data collection is done through the analysis of documents, interviews and observation. The findings in this study indicate that the construction of broadcasting regulation in the era of convergence needs to be done, where the technologies previously separate increasingly integrated into one. The convergence of these technologies in its various form shas been used by our society, such as HP and the Internet. While still not optimal Broadcasting Commission Indonesia (KPI) role. Thus the Broadcasting Act in for ceduring this time, should berevised because it is no longer relevant to the development of ICT.
\end{abstract}

Keywords: Construction, Regulation, Broadcasting, Convergence Era.

\begin{abstract}
Abstrak
Penelitian ini membahas konstruksi regulasi penyiaran berdasarkan UU Penyiaran Nomor 32 tahun 2002 dimana pada era Konvergensi memuat pasal-pasal yang dinilai sudah tidak sesuai lagi dengan perkembangan Teknologi Informasi dan Komunikasi (TIK). Paradigma yang digunakan dalam penelitian ini adalah paradigma konstruktivisme. Sedangkan pendekatannya adalah pendekatan kualitatif. Untuk pengumpulan data dilakukan melalui dokumen analisis, wawancara mendalam dan observasi. Hasil temuan dalam penelitian ini menunjukkan bahwa regulasi penyiaran di era konvergensi perlu dilakukan revisi karena teknologi media yang sebelumnya terpisah semakin terintegrasi menjadi satu. Konvergensi teknologi ini dalam berbagai bentuknya telah dimanfaatkan oleh masyarakat seperti HP dan internet. Sementara peran Komisi Penyiaran Indonesia (KPI) masih belum optimal. Dengan demikian UU Penyiaran yang berlaku selama ini, harus segera direvisi karena sudah tidak sesuai lagi dengan perkembangan TIK.
\end{abstract}

Kata Kunci : Kontruksi, Regulasi, Penyiaran, Era Konvergensi. 


\section{PENDAHULUAN}

Perkembangan Teknologi Informasi dan Komunikasi (TIK) saat ini begitu cepat, membawa pengaruh yang luar biasa terhadap kehidupan manusia di segala bidang, termasuk dunia penyiaran di Indonesia.

Sementara regulasi penyiaran dinilai sudah tidak sesuai lagi dengan perkembangan TIK. Pada saat ini kebijakan atau regulasi beberapa perundang-undangan dinilai masih terpisah satu sama lain dan masih tumpang tindih, sehingga timbul berbagai reaksi dari masyarakat, pengusaha penyiaran, termasuk asosiasi penyiaran, dan pemerhati media.

Peraturan yang dinilai masih tumpang tindih, antara lain, adalah UU No. 32 Tahun 2002 tentang Penyiaran, UU No. 36 Tahun 1999, tentang Telekomunikasi, dan UU No. 11 Tahun 2008 tentang Informasi dan Tranksasi Elektronik.

Kementerian Komunikasi dan Informatika (Kemenkominfo) sebagai regulator penyiaran, sesuai dengan UU Penyiaran, mengamanatkan kepada Komisi Penyiaran Indonesia (KPI) sebagai pelaksana yang mengawasi isi siaran dan menyusun peraturan dan menetapkan pedoman perilaku penyiaran.

Sementara kasus-kasus pelanggaran yang terjadi dalam penyiaran antara lain:

1. Terkait dengan pasal 5 (g) UndangUndang Penyiaran No 32 Tahun 2002 yang berbunyi mencegah monopoli kepemilikan dan mendukung persaingan yang sehat dalam bidang penyiaran. Namun pada kenyataanya, kondisi persaingan lembaga penyiaran di Indonesia saat ini mulai menunjukkan pada arah yang kurang sehat. Seperti yang terjadi pada lembaga penyiaran Media Nusantara Citra (MNC) dengan mendominasi kepemilikan saham televisi, radio dan media cetak serta menguasai $100 \%$ saham situs okezone.com. (http://bahankuliahikomunand.files.wordp ress.com)

2. Program tayangan "Kakek-Kakek Narsis (KKN)". "Tayangan ini telah menempatkan perempuan menjadi objek subordinasi". Diskriminasi terhadap perempuan tersebut memang jelas diperlihatkan melalui muatan tayangan yang terdiri dari perkataan, komentar, dialog, dan interaksi pengisi acara tayangan tersebut. Dan konsekuensinya, hal tersebut dapat memicu pada belbagai bentuk kekerasan terhadap perempuan (http://icrp-online.org)

Dunia penyiaran/broadcast (terkait Televisi dan Radio), diatur oleh satu regulator tersendiri, yakni KPI, yang diamanatkan oleh UU No. 32 Tahun 2002 tentang Penyiaran. Sementara regulator untuk TIK diatur oleh suatu Lembaga Regulasi Telekomunikasi yang bernama Badan Regulasi Telekomunikasi Indonesia (BRTI), sebagai pelaksana dari UU No. 36 Tahun 1999, yaitu tentang Telekomunikasi. BRTI ditetapkan Pemerintah melalui Keputusan Menteri Perhubungan No. 31/2003 tanggal 11 Juli 2003. Sementara mengenai Struktur Organisasi Badan Regulasi Telekomunikasi Indonesia diatur berdasarkan Permen Kominfo No.36/2008.

Era konvergensi sudah dimulai sejak internet diperkenalkan sekitar tahun 1982, dan dipopulerkan oleh Negroponte. Roger Fidler dalam Mediamorphosis; Understanding New Media, mengakui konvergensi industri media dan teknologi digital terjadi dan membentuk komunikasi multimedia atau media campuran menyatukan dua bentuk komunikasi atau lebih. Jadilah saat ini kita bisa menonton, mendengarkan lagu, sekaligus membaca teks secara bersamaan. (Haryati, 2008)

Di ranah penyiaran, saat ini konvergensi kepemilikan sudah terjadi, seperti Kelompok/Group: MNC memiliki 3 stasiun TV \& 4 Radio, TransCorp memiliki 2 stasiun TV, Jaringan Delta Female Indonesia (JDFI) memiliki 6 Stasiun Radio, dan Mugi Relso Abadi (MRA) memiliki 5 Stasiun Radio, dan Grup Jawa Pos yang memiliki afiliansi surat kabar dan stasiun televisi yang tersebar di wilayah Indonesia..

Undang-undang Penyiaran No. 32 Tahun 2002 kemudian mengamanatkan supaya terbentuk KPI yang bertugas untuk merumuskan suatu pedoman dan standar 
program penyiaran serta mengawasi tayangan di Indonesia.

Baru tiga bulan UU Penyiaran disahkan, muncul berbagai kritikan dan pengaduan oleh pihak yang merasa terancam oleh keberadaan KPI. Pihak itu tidak lain adalah para pengusaha penyiaran, yang di dalamnya terdapat beberapa asosiasi penyiaran. Mereka mengajukan permohonan peninjauan kembali (judicial review) kepada Mahkamah Agung (saat itu, awal 2003, Mahkamah Konstitusi belum dibentuk dan baru dibentuk pertengahan 2003).

KPI hanya berwenang dalam bidang isi siaran. Mengenai bidang infrastruktur dan perizinan, posisi KPI berada di bawah pemerintah yang berfungsi sebagai pemberi rekomendasi dan keputusan berada di Kementerian Komunikasi dan Informatika (Kemenkominfo). Proses uji materi UU Penyiaran ini merupakan salah satu contoh, dari berbagai kasus di bidang lain selain penyiaran, kontestasi antara para kapitalis penyiaran, negara, dan masyarakat di akar rumput penggiat penyiaran (http://catatancalonwartawan.wordpress.com).

Munculnya beberapa tuntutan dari masyarakat atau dari beberapa asosiasi dan pengusaha penyiaran, serta berkembangnya TIK yang sangat cepat ini menimbulkan pemikiran dari atau masyarakat, para pemerhati media, pemerintah dan Dewan Perwakilan Rakyat untuk merevisi atau menggabungkan beberapa undang-undang yang berhubungan dengan penyiaran, elektronik, dan telekomunikasi. Hal ini yang menarik untuk diteliti. Permasalahan pokok penelitian ini dapat dirumuskan sebagai berikut: Bagaimana Konstruksi Regulasi Penyiaran Di Era Konvergensi? Identifikasi masalahnya adalah, 1) Bagaimana konstruksi regulasi mengenai kesesuaian isi siaran dan izin penyelenggaraan siaran pada UndangUndang Penyiaran?; 2). Bagaimana konstruksi regulasi mengenai kepemilikan lembaga penyiaran pada Undang-Undang Penyiaran?; 3). Bagaimana peran Komisi Penyiaran Indonesia apabila ada pelanggaran terhadap UU penyiaran?; serta 4). Bagaimana konstruksi regulasi penyiaran setelah berkembangnya TIK di era konvergensi?.
Adapun tujuan penelitian, adalah 1). Ingin mengetahui konstruksi regulasi mengenai isi siaran dan izin penyelenggaraan siaran pada Undang-Undang Penyiaran, 2). Ingin mengetahui konstruksi regulasi mengenai kepemilikan lembaga penyiaran pada Undang-Undang Penyiaran. 3). Ingin mengetahui peran Komisi Penyiaran Indonesia apabila ada pelanggaran terhadap UU penyiaran. 4). Ingin mengetahui konstruksi regulasi penyiaran setelah berkembangnya TIK di era konvergensi. Manfaat penelitian: Diharapkan menjadi masukan bagi pemerintah dalam hal ini Kementerian Komunikasi dan Informatika tentang konstruksi regulasi penyiaran, dilihat dari isi siaran, izin penyelenggaraan siaran dan kepemilikan lembaga penyiaran sesuai dengan Undang-Undang Penyiaran (UU No. 32 Tahun 2002); Diharapkan menjadi masukan bagi penyelenggara penyiaran, pengusaha penyiaran dan assosiasi penyiaran serta masyarakat tentang konstruksi regulasi penyiaran saat ini dan regulasi yang ideal di era konvergensi.; Diharapkan menjadi masukan bagi KPI yang akan datang dalam menangani pelanggaran yang terjadi dalam penyiaran, sehingga mampu menciptakan keadaan yang kondusif dalam hal penyiaran.

\section{LANDASAN KONSEP}

\section{Model Regulasi Penyiaran}

Dalam hubungannya dengan model kepemerintahan suatu negara, Leen d'Haenens (2000, lihat pula Me-Quail, 1983) membagi model regulasi penyiaran menjadi lima, yakni: 1) Model Otoriter; 2) Model Komunis; 3) Model Barat-Paternalistik; 4) Model Barat-Liberal; dan 5) Model Demokratis-Partsipan.

Model regulasi yang dianggap sesuai untuk penyiaran di Indonesia adalah model yang terakhir yaitu "Model demokratisPartisipan".

Asumsi dari Model DemokratisParticipan antara lain: 1) Right to communicate; 2) Organisasi dan isi tidak perlu tunduk pada pengendalian birokrasi; 3) 
Eksistensi media ditunjukkan untuk kepentingan khalayak; 4) Orang, kelompok dan komunitas lokal memiliki media sendiri; 5) Bentuk media berskala kecil, interaktif, partisipasi lebih baik.; 6) Kebutuhan sosial tertentu; dan 7) Komunikasi terlalu penting untuk hanya diserahkan kepada kelompok profesional.

Model ini dikembangkan oleh mereka yang mempercayai sebagai powerful medium, dan dalam banyak terinspirasi oleh mazhab kritis, termasuk dalam model ini adalah berbagai media penyiaran alternatif. Sifat komunikasi dalam model ini adalah dua arah (two-way-communication).

Secara fundamental, regulasi penyiaran mesti mengandung substansi yang:

1. Menetapkan sistem tentang bagaimana dan siapa yang berhak mendapatkan lisensi penyiaran.

2. Memupuk rasa nasionalitas. Hal ini berangkat dari asumsi bahwa radio dan televisi memiliki peran yang penting dalam mengembangkan kebudayaan sekaligus sebagai agen pembangunan bangsa, bahkan ketika suatu negara tengah dilanda krisis sekalipun.

3. Secara ekonomis, melindungi institusi media domestik dari "kekuatan" asing.

4. Semangat di atas, mencegah konsentrasi dan untuk membatasi kepemilikan silang. Di Uni Eropa ada komisi khusus yang mengatur tata laksana merger dan pengawas kuota media.

5. Memuat apa yang disebut Head (1985) sebagai "regulator of fairness" yang memuat prinsip objektivitas, imparsialitas, dan akuntabilitas. Prinsipprinsip tersebut diperlukan untuk membangun media yang sehat juga untuk menjaga keseimbangan hubungan antara pengelola penyiaran, pemerintah, dan audien.

6. Mengatur tata-aliran keuangan dari sumber yang berbeda. Dana komersial, misalnya mesti dibatasi guna melindungi konsumen dari iklan yang eksesif, paling tidak dari bentuk promosi tertentu dan untuk mencegah pengaruh pengiklan yang berlebihan terhadap suatu acara. (Mufid Muhammad, 2010)
Pada praktiknya, keenam prinsip regulasi penyiaran tersebut diterapkan secara bervariatif tergantung bentuk model penyiaran yang ada di suatu negara.

Dalam konteks diversitas politis dan kultural, regulasi penyiaran juga mesti berisi peraturan yang mencegah terjadinya monopoli atau penyimpangan kekuatan pasar, proteksi terhadap nilai-nilai pelayanan publik (public service values) dan pada titik tertentu berisi pula aplikasi sensor yang bersifat paternalistik (Mufid Muhammad, 2010)

\section{Konstruksi Regulasi Penyiaran}

Istilah konstruksi sosial atas realitas (social construction of reality), menjadi terkenal sejak diperkenalkan oleh Peter L. Berger dan Thomas Luckmann melalui bukunya yang berjudul "The Social construction of Reality, a Treatise in the Socialogical of Knowledge” (1966). Mereka menggambarkan proses sosial melalui tindakan dan interaksinya, yang mana individu menciptakan secara terus-menerus suatu realitas yang dimiliki dan dialami bersama secara subjektif (Berger and Luckmann, 1990)

Asal mula konstruksi sosial dari filsafat konstruktivisme, yang dimulai dari gagasan-gagasan konstruktif kognitif. Menurut Von Glasersfeld, pengertian konstruktif kognitif muncul pada abad ini. Dalam tulisan Mark Baldwin yang secara luas diperdalam dan disebarkan oleh Jean Piaget. Namun apabila ditelusuri, sebenarnya gagasan-gagasan pokok konstruktivisme sebenarnya telah dimulai oleh Giambatissta Vico, seorang epistemologi dari Italia, Ia adalah cikal bakal konstruktivisme (Suparno, 1997 dalam Bungin, 2008).

Keseluruhan tarik-menarik penilaian terhadap regulasi Penyiaran (UU No. 32 Tahun 2002) jika dianalisis dengan menggunakan teori 'social construction of reality dari Berger dan Lucmann (1966) pada hakikatnya juga mencerminkan perbedaan para pihak dalam mengonstruksi UU Penyiaran sebagai sebuah realita.

Menurut Berger dan Lucmann(1966, lihat juga Hidayat, 2003) proses 
mengontruksi berlangsung melalui interaksi sosial yang dialektis dari tiga bentuk realitas, yakni symbolic reality, objective reality, dan subjective reality yang berlangsung dalam suatu proses dengan tiga simultan; eksternalisasi, objektivasi, dan internalisasi. Obyective reality merupakan suatu kompleksitas definisi realitas (termasuk ideologi dan keyakinan) serta rutinitas tindakan dan tingkah laku yang telah mapan terpola (tercakup di dalamnya adalah berbagai institusi sosial dalam pasar), yang kesemuanya dihayati oleh individu secara umum sebagai fakta. Symbolic reality merupakan semua ekspresi simbolik dari apa yang dihayati sebagai 'objective reality', termasuk di dalamnya teks produk industri media, representasi pasar, kapitalisme, dan sebagainya dalam media. Sedangkan subjective reality merupakan konstruksi definisi realitas (dalam hal ini misalnya media, pasar, dan seterusnya) yang dimiliki individu dan dikonstruksi melalui proses internalisasi.

Realitas subjektif yang dimiliki masing-masing individu merupakan basis untuk melibatkan diri dalam proses eksternalisasi, atau proses interaksi sosial dengan individu lain dalam sebuah tatanan sosial. Melalui proses eksternalisasi itulah individu secara kolektif berpotensi melakukan objektivikasi baru, memunculkan sebuah konstruksi objective reality yang baru (Hidayat, 2003).

Berger menyebut kondisi
keberlangsungan antara yang subjektif ${ }^{n}$ dan


objektivasi-internalisasi. Eksternalisasi menunjuk pada penyesuaian diri dengan dunia sosio-kultural sebagai produk manusia. Objektivasi merupakan interaksi sosial dalam dunia intersubjektif yang dilembagakan atau mengalami institusionalisasi. Sedangkan internalisasi adalah identifikasi diri individu di tengah lembaga sosial atau organisasi sosial dimana individu terlibat. Manusia dan masyarakat, dengan demikian, adalah produk sekaligus konstruksi sosial. (Mufid, 2010)

\section{UU Penyiaran No 32 Tahun 2002}

Menurut UU No. 32/2002 kini dan kelak jasa penyiaran di Indonesia diselenggarakan oleh empat jenis lembaga yakni lembaga penyiaran publik (kita akan mengenal dan memiliki Radio dan TV Publik), lembaga penyiaran swasta (Radio dan TV Swasta), lembaga penyiaran komunitas (Radio dan TV Komunitas), dan lembaga penyiaran berlangganan (Radio dan TV Berlangganan). (Saragih, 2004).

Klasifikasi lembaga penyiaran ini mencerminkan pluralitas pemilikan dan isi media yang dapat menjadi saluran informasi berbagai kalangan di masyarakat. Hal mengenai monopoli dan modal asing pada media penyiaran, juga dibatasi.

\section{Komisi Penyiaran Indonesia (KPI)}

Komisi Penyiaran Indonesia (KPI) merupakan lembaga negara regulator penyiaran independen yang kelahirannya merupakan amanat dari Undang-Undang (UU) Nomor 32 Tahun 2002 tentang Penyiaran. UU Nomor 32 Tahun 2002 merupakan pengganti UU Penyiaran terdahulu, yaitu UU Nomor 24 Tahun 1997 yang kental dengan nuansa otoriter.

Eksistensi KPI adalah bagian dari wujud peran serta masyarakat dalam hal penyiaran, baik sebagai wadah aspirasi maupun mewakili kepentingan masyarakat (UU Penyiaran, pasal 8 ayat 1). Legitimasi politik bagi posisi KPI dalam kehidupan kenegaraan berikutnya secara tegas diatur oleh UU Penyiaran sebagai lembaga negara independen yang mengatur hal-hal mengenai penyiaran (UU Penyiaran, pasal 7 ayat 2). Secara konseptual posisi ini mendudukkan KPI sebagai lembaga yang dikuasi negara atau dalam istilah lain juga biasa dikenal dengan auxilarry state institution.

\section{Pengertian Konvergensi}

Beberapa definisi Konvergensi dari beberapa lembaga yang berbeda:

1. Kemampuan beberapa platform network yang berbeda untuk membawa tipe aplikasi dan layanan yang secara esensial 
sama. (European Union, 1998)

2. Konvergensi Digital, bisa dilihat sebagai kebersamaan (pertemuan/konvergensi) antara yang sebelumnya secara teknologi dan pasar/market terpisah, seperti broadcasting, print publishing, cable television, telepon suara fixed wired, komunikasi seluler dan Fixed wireless access, (ITU, 1999).

3. Sebuah proses yang melibatkan jaringan dan layanan komunikasi, yang sebelumnya terpisah, ditransformasikan sedemikian rupa, sehingga jaringan dan layanan yang berbeda bisa membawa layanan voice, audio-visual, dan data yang sama. Selain itu, beberapa perlengkapan konsumen yang berbeda juga bisa menggunakan layanan tersebut, layanan baru akan diciptakan (OECD, 2000).

Kemajuan-kemajuan yang dicapai oleh teknologi komputasi dan peralatan elektronik, mengakibatkan semakin terdorongnya penemuan-penemuan teknologi baru yang melahirkan sebuah fenomena yang kerap dikenal sebagai konvergensi. Secara sederhana konvergensi dapat dipahami sebagai menyatunya unsur-unsur dalam teknologi komputasi, telekomunikasi, media, dan penyiaran sehingga batas-batasnya menjadi kabur.

Fenomena konvergensi ini semakin nyata dengan keberadaan internet sebagai sebuah jaringan komunikasi global yang terdiri dari ribuan jaringan independen dan jutaan komputer di seluruh dunia yang secara bersama-sama berfungsi sebagai medium pertukaran informasi. Pada sisi lain, internet adalah ruang maya yang bersifat publik, yang dapat digunakan orang-orang di seluruh dunia untuk bertemu dan saling mempertukarkan ide, dipergunakan perusahaan-perusahaan untuk bersaing mendapatkan konsumen, dan berbagai kegiatan lainnya yang secara konvensional diselenggarakan di dunia nyata. Internet telah menyajikan sebuah "dunia baru" yang paling mendekati pengertian dari istilah cyberspace.

Perubahan yang sedemikian revolusionernya dalam bidang teknologi yang tidak hanya memengaruhi hukum, namun juga hampir seluruh pranata sosial lainnya memaksa hukum sebagai pranata sosial untuk meninjau dan mengkaji ulang berbagai aspeknya (Mujtaba Hamdi, 2011).

Rencana Pemerintah bersama DPR membuat UU Konvergensi, mendapat tanggapan dari berbagai pihak. Salah satu yang memberi tanggapan adalah masyarakat yang tergabung dalam Perkumpulan Media Link 27.12.2011. Dalam tulisannya antara lain:

1. Jauh lebih penting dari konvergensi adalah, bagaimana kita mengambil keputusan mengenai arahnya: menguntungkan kita semua, warga negara Indonesia keseluruhan, rakyat semua, atau menguntungkan hanya bagi segelintir orang? (Dalam penelitian ini, regulasi penyiaran yang diharapkan adalah menguntungkan semua pihak).

2. Konvergensi Industri. Konvergensi media bukan sekadar konvergensi teknologi (teknologi informasi, telekomunikasi + penyiaran). Tapi konvergensi media juga terkait konvergensi kepemilikan usaha. Di ranah penyiaran, konvergensi kepemilikan sudah terjadi, akan terus jadi tren jika tak dikontrol.

3. RUU Konvergensi justru lebih memberi jalan korporasi untuk semakin mengomoditaskan informasi, ketimbang melindungi kepentingan dan hak warga negara atas informasi. "informatika sebagai komoditas", "pembukaan pasar", dst. Pasal 30: "Setiap Penyelenggara Telematika dapat melakukan penggabungan, peleburan atau pengambilalihan usaha dengan Penyelenggara Telematika lainnya."

4. Upaya legalisasi juga lewat draft revisi UU Penyiaran. Pasal-pasal pembelaan terhadap korporasi sangat kentara; penyiaran publik dan penyiaran komunitas kian tak diberi ruang. Pindah tangan frekuensi jadi sah; lewat jual beli saham.

5. RUU Konvergensi juga makin melemahkan hak warga di hadapan korporasi. Pasal 11: "Penyelenggaran 


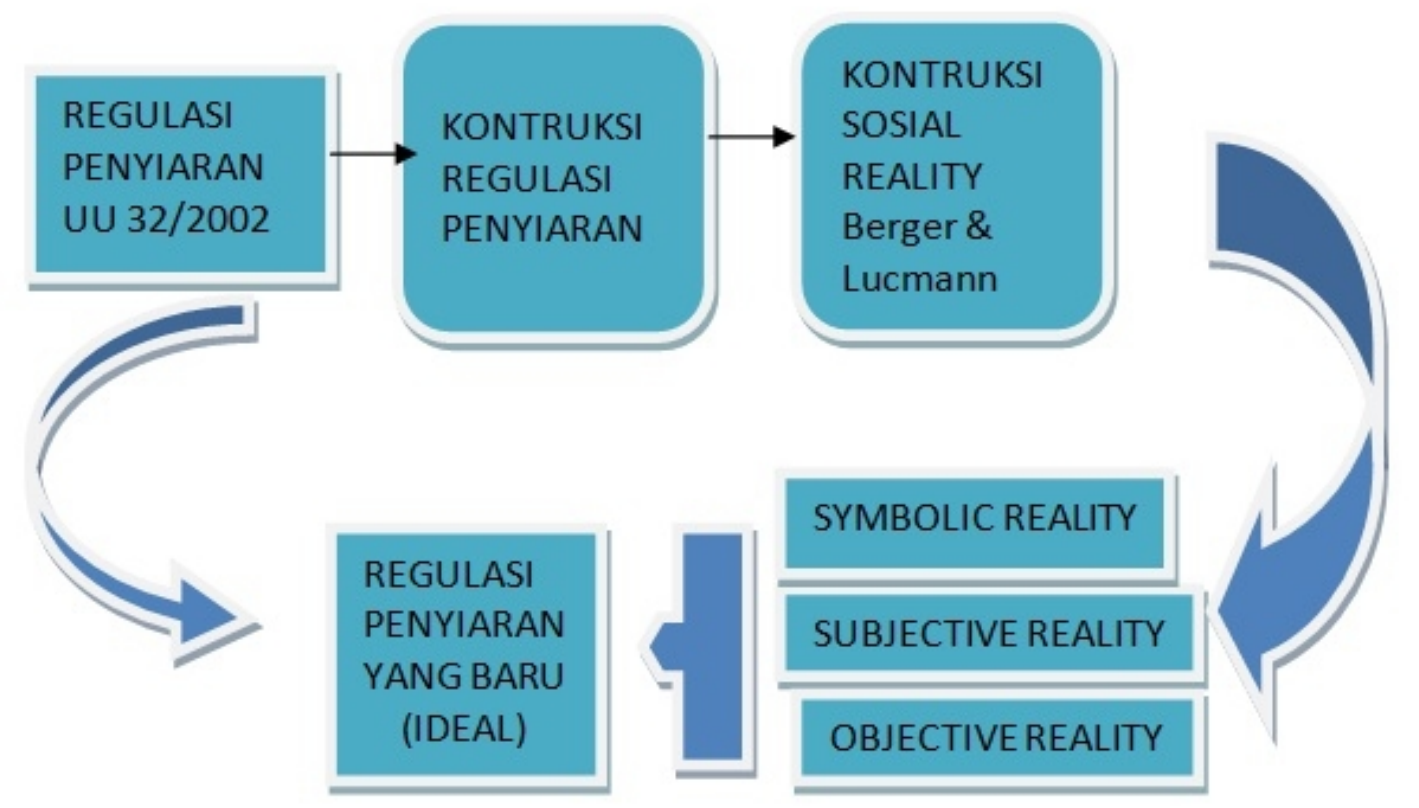

Gambar 1

Konstruksi Regulasi Penyiaran Yang Ideal

Telematika dapat memanfaatkan atau melintasi tanah dan/atau bangunan milik perseorangan atau badan hukum untuk tujuan pembangunan, pengoperasian, dan/atau pemeliharaan fasilitas jaringan telematika." Tak ada hak gugat, hanya "kewajaran harga". Picu konflik agraria.

6. Regulasi konvergensi media harus mempertimbangkan kepentingan publik dan kepentingan profesional, tidak hanya kepentingan korporat. Ruang yang setara dan seimbang harus juga diberikan kepada lembaga penyiaran publik dan lembaga penyiaran komunitas. Regulasi mendesak bukan untuk konglomerasi melainkan utk melindungi kepentingan publik. (Hamdi, 2011)

Dari uraian di atas, penulis mencoba menggambarkan kerangka pemikiran penelitian ini ke dalam suatu model seperti pada gambar 1 .

\section{METODE PENELITIAN}

Metode yang di gunakan dalam penelitian ini adalah kualitatif melalui pedekatan konstruktivisme. Metode kualitatif bertujuan untuk menjelaskan fenomena melalui pengumpulan data sedalam-dalamnya. Melalui wawancara dan observasi dapat diketahui apakah regulasi penyiaran (UU No. 32 Tahun 2002) masih sesuai dengan perkembangan saat ini di era konvergensi, atau perlu segera direvisi. Sedangkan perspektif konstruktivism adalah perbedaan penilaian para pihak dalam mengonstrunstruksi UU Penyiaran sebagai sebuah realita.

Perspektif yang penulis gunakan dalam penelitian ini adalah perspektif emik, artinya hasil penelitian berdasarkan pernyataan murni dari informan. Instrumen Penelitian dilakukan sendiri oleh penulis, karena penulis merupakan instrumen utama (instrumen tunggal) dalam penelitian. Menurut Nasution dalam (Sugiyono, 2005).

Data dianalisis secara deskriptif kualitatif, lalu disajikan dalam bentuk naratif juga ditampilkan dalam bentuk kategori model atau bagan. Lokasi penelitian : Kabupaten/Kota Sukabumi. Instrumen Penelitian: (1) Sebagai data kualitatif, dilakukan wawancara mendalam yang dipandu langsung oleh peneliti terhadap para informan yang sengaja dipilih. (2) Dokumentasi. Penulis memperoleh data 
Tabel 1

Profil Informan

\begin{tabular}{|c|c|c|c|c|c|}
\hline NO & NAMA & USIA & JABATAN & ALAMAT & NO HP/TELP \\
\hline 1 & Pampam Pamungkas & 57 th & Pemilik Kiwari Radio & $\begin{array}{l}\text { Jl. Raya } \\
\text { Cibeureum }\end{array}$ & $\begin{array}{l}087820887890 / \\
0266246563\end{array}$ \\
\hline 2 & Liana Meulina & 21 th & $\begin{array}{l}\text { Script Writer dan Announcer } \\
\text { Kiwari Radio }\end{array}$ & $\begin{array}{l}\text { Sukabum1 } \\
\text { Cikaret Jl. } \\
\text { Goalpara }\end{array}$ & 087721737226 \\
\hline 3 & Andri Sofiandi, SE & 37 th & Finance Kiwari Radio & $\begin{array}{l}\text { Sukaraja - } \\
\text { Sukabumi }\end{array}$ & 081911988854 \\
\hline 4 & Bob DC Pratikno, Drs & 75 th & $\begin{array}{l}\text { Manager Program } \\
\text { ATV Sukabumi }\end{array}$ & $\begin{array}{l}\text { Jl. Pasir } \\
\text { Salamet No } 36 \\
\text { Sukabumi }\end{array}$ & $\begin{array}{l}08157001808, \\
082111132606, \\
087721625808, \\
08381848606\end{array}$ \\
\hline 5 & I Thoriq Mubarak, SP. SE. & 31 th & $\begin{array}{l}\text { Direktur Operasional } \\
\text { ATV Sukabumi }\end{array}$ & $\begin{array}{l}\text { Griya Cimah- } \\
\text { par Endah I }\end{array}$ & 085659688222 \\
\hline 6 & Lestari Handayani & 33 th & $\begin{array}{l}\text { HRD (Human Resources De- } \\
\text { pelopment) ATV Sukabumi }\end{array}$ & $\begin{array}{l}\text { Komplek } \\
\text { Taman Asri } \\
\text { Sukabumi }\end{array}$ & 085624409932 \\
\hline
\end{tabular}

Sumber : Hasil Wawancara tanggal 14 \& 15 Juni 2012.

tambahan mengenai objek dan subjek penelitian melalui sumber-sumber berupa dokumen-dokumen.

\section{Subjek Penelitian}

Penentuan informan dan jumlahnya dilakukan sesuai dengan kebutuhan dalam penelitian. Informan dalam penelitian ini adalah pemerhati media (pengamat media massa), pemilik perusahaan/penanggung jawab, pengelola dan karyawan perusahaan penyiaran dari daerah yang telah ditentukan menjadi daerah penelitian. Jumlah informan dalam penelitian ini sebanyak 6 orang, terdiri dari pemilik Kiwari Radio Sukabumi, Manager Program ATV Sukabumi, Finance Kiwari Radio dan yang lainnya. Secara lengkap akan disajikan dalam Tabel 1.

\section{HASIL PENELITIAN DAN PEMBAHASAN}

Analisis data penelitian ini meliputi: analisis penyiaran berdasarkan UU Nomor 32 Tahun 2002, yang terdiri dari regulasi/kebijakan, isi undang-undang, izin penyelenggaraan siaran, kepemilikan dan kasus-kasus penyiaran. Analisis KPI sekarang dan pada masa yang akan datang. Serta analisis konstruksi regulasi penyiaran dan regulasi di era konvergensi.

\section{UU Penyiaran}

\section{Regulasi UU Penyiaran}

Regulasi/kebijakan UU penyiaran yang telah ada selama ini menurut informan dinilai masih sesuai dengan perkembangan teknologi informasi, mengingat dalam regulasi itu sudah memuat peraturan yang mengikat. Hal ini dikemukakan oleh Manager Program ATV Sukabumi, Bob DC Pratikno. Namun, berbeda dengan pendapat informan lainnya, Liana Meulina dari Kiwari Radio (wawancara tanggal 14 Juni 2012) mengatakan bahwa :

"Regulasi/kebijakan tentang penyiaran yang ada sudah tidak sesuai, karena kemajuan teknologi penyiaran yang berkembang dengan cepat menyebabkan landasan hukum pembinaan dan pengembangan yang ada selama ini sudah tidak memadai lagi, baik karena tingkat peraturan 
yang mengaturnya lebih rendah dari pada undang-undang maupun karena ruang lingkup peraturannya baru meliputi segi-segi tertentu dalam kegiatan penyiaran dengan peraturan yang belum terpadu”

Pernyataan Liana Meulina didukung oleh informan Andi Sofiandi dari Kiwari Radio (wawancara tanggal 14 Juni 2012) yang menyatakan :

"Regulasi/kebijakan tentang penyiaran yang telah ada selama ini, dirasakan belum memadai; karena perkembangan teknologi komunikasi dan informasi telah melahirkan masyarakat informasi yang makin besar tuntutannya akan hak untuk mengetahui dan hak untuk mendapatkan informasi. Informasi telah menjadi kebutuhan pokok bagi masyarakat dan telah menjadi komoditas penting dalam kehidupan bermasyarakat, berbangsa, dan bernegara. Perkembangan teknologi komunikasi dan informasi tersebut telah membawa implikasi terhadap dunia penyiaran, termasuk penyiaran di Indonesia. Penyiaran sebagai penyalur informasi dan pembentuk pendapat umum, perannya makin strategis, terutama dalam mengembangkan alam demokrasi di Negara kita. Penyiaran telah menjadi salah satu sarana berkomunikasi bagi masyarakat, lembaga penyiaran, dunia bisnis, dan pemerintah. Perkembangan tersebut telah menyebabkan landasan hukum pengaturan penyiaran yang ada selama ini menjadi tidak memadai",

\section{Dilihat Dari Isi UU Penyiaran}

Bila dilihat dari isi pasal-pasal yang ada di dalam UU Penyiaran, menurut beberapa informan, bahwa isi pasal-pasalnya masih sesuai namun ada beberapa poin yang dalam pelaksanaannya mengalami pergeseran. Seperti apa yang dikatakan oleh salah satu informan yang bernama Andry Sofiandi dari
Kiwari Radio (wawancara tanggal 14 Juni 2012). Sebagai berikut :

"Isi pasal-pasal dalam UU penyiaran masih sesuai, namun ada beberapa poin dalam pelaksanaannya mengalami pergeseran, seperti pasal 16 - 20 (Lembaga Penyiaran Swasta). Pasal 18 menunjukkan hal yang jelas, dalam satu wilayah penyiaran pemilik tidak diperbolehkan mempunyai media lebih dari satu. Sementara pasal 31 ayat 6 menyebutkan, kepemilikan penyiaran lokal diutamakan masyarakat yang tinggal di wilayah tersebut. Namun dalam kenyataanya banyak radio yang merupakan anak perusahaan MNC".

Pada bagian lain, Andry mengatakan: "Melihat pasal 36 dari BAB IV tentang pelaksanaan siaran memang dapat menggambarkan isi siaran yang ideal. Tapi pada kenyataannya stasiun TV yang hampir didominasi oleh pihak swasta cenderung menampilkan atau menayangkan program-program yang kurang menonjolkan budaya Indonesia, malah lebih menonjolkan budaya dari luar negeri akibat pengaruh globalisasi. Contohnya di stasiun Global TV. Beberapa tahun sebelumnya, siaran stasiun tersebut didominasi oleh siaran MTV (Music Television). Selain itu, dari sisi pembentukan moral bangsa materi siaran yang ditampilkan ada yang mengandung unsur kekerasan dan terdapat istilah asing yang berkonotasi negatif'.

\section{Dilihat Dari Izin Penyelenggaraan Siaran}

Izin penyelenggaraan siaran menurut undang-undang yang telah ada ternyata seluruh informan menyatakan bahwa izin siaran sudah tidak sesuai lagi dengan perkembangan zaman di era informasi. Seperti yang dikemukakan oleh informan dari ATV Sukabumi Bob DC Pratikno (wawancara tanggal 15 Juni 2012) sebagai berikut:

$$
\text { "Bila dilihat dari izin }
$$


penyelenggaraan siaran yang ada dalam UU Penyiaran, sudah tidak sesuai; karena hanya lembaga Penyiaran Publik yang dapat menjangkau seluruh wilayah NKRI, tapi pada kenyataannya banyak Penyiaran Swasta yang mampu menjangkau seluruh wilayah karena mempunyai anak perusahaan yang me-relay acaranya untuk sampai ke seluruh wilayah Indonesia. Sementara Lembaga penyiaran swasta jangkauannya terbatas."

Hal senada disampaikan oleh informan Andry Sofiandi dari Kiwari Radio (wawancara tanggal 14 Juni 2012) yang mengatakan :

"Izin penyelenggaraan siaran yang ada selama ini sudah tidak sesuai dengan perkembangan zaman, dimana undang-undang No. 32 Tahun 2004 tentang Pemerintahan Daerah, harusnya izin penyelenggaraan siaran diserahkan ke Pemerintah Daerah".

Sementara pendapat yang lebih keras datang dari informan Liana Meutia sebagai Script Writer \& Announcer Kiwari Radio (wawancara tanggal 14 Juni 2012), yang mengatakan bahwa masalah perizinan sudah sangat tidak sesuai dengan perubahan di era sentralisasi ke era desentralisasi. Sebagai berikut :

"Sesuai UU 32 tahun 2004 tentang Pemerintah Daerah kewenangan daerah telah diperluas termasuk Gubernur sebagai wakil Pemerintah Pusat di daerah dalam rangka desentralisasi. Jadi mengenai perizinan penyelenggaraan siaran radio yang dikelola oleh swasta tidak perlu mendapat izin langsung dari Menteri Komunikasi dan Informatika, akan tetapi cukup oleh Gubernur sebagai wakil Pemerintah pusat di daerah. Regulasi perizinan ini penting untuk tumbuhnya industri kreatif di daerah. Pertumbuhan ini seharusnya didorong oleh pemerintah dengan regulasi pemangkasan izin yang dinilai terlalu jelimet”.

\section{Dilihat Dari Kepemilikan}

Kepemilikan media bila dilihat dari UU penyiaran yang telah ada ternyata semua informan mengatakan sudah tidak sesuai. Seperti diungkapkan oleh informan dari ATV Bob DC Pratikno (wawancara tanggal 15 Juni 2012) yaitu:

"Kepemilikan menurut UU penyiaran saat ini sudah tidak sesuai lagi, karena ada beberapa stasiun dikuasai oleh satu perusahaan. Sebagai contoh sebuah perusahaan menguasai beberapa stasiun TV maupun Radio, antara lain MNC Group menguasai 3 stasiun TV dan 4 stasiun Radio, stasiun JDH menguasai 5 stasiun radio, stasiun MRA meguasai 5 stasiun radio, Emitex menguasai 3 stasiun TV dan Visi Media Asia menguasai 2 stasiun TV”.

Hal yang hampir sama disampaikan oleh informan lain dari Kiwari Radio Andry Sofiandi (wawancara tanggal 14 Juni 2012). Secara lengkap dia mengatakan:

"Apa yang terkandung dalam pasal 18 menunjukkan hal yang jelas, dalam satu wilayah penyiaran pemilik tidak diperbolehkan mempunyai media lebih dari satu. Berdasarkan kepemilikan dari UU penyiaran untuk saat ini sudah tidak sesuai dengan perkembangan saat ini, dimana pemusatan kepemilikan lembaga penyiaran swasta berpotensi dimanfaatkan untuk menggiring opini publik. Dampak pemusatan kepemilikan itu akan lebih berbahaya lagi jika pemiliknya terafiliasi dengan partai politik tertentu. Penyiaran memang perlu diatur secara ketat sesuai dengan karakteristiknya dalam menayangkan informasi pengetahuan untuk masyarakat. Yang terjadi sekarang mengalami konsentrasi kepemilikan bahkan terdapat konsentasi kepemilikan silang hingga 
radio dan harian nasional”.

\section{Dilihat Dari Kasus-Kasus Penyiaran}

Kasus-kasus penyiaran selama ini masih banyak yang hanya mendapat teguran saja dari KPI, namun untuk selanjutnya kasus tersebut tidak tahu ujungnya; atau acaranya tetap berjalan hanya nama acara yang dirubah sedikit. Seperti acara "Empat Mata" diubah jadi "Bukan Empat Mata" dari Trans7. Di bawah ini akan disajikan beberapa pendapat informan, seperti Andry Sofiandi dari Kiwari Radio (wawancara tanggal 14 Juni 2012) yang mengatakan;

Beberapa kasus dalam penyiaran antara lain:

a. Program tayangan Indonesia Lawyers Club (TV One), dimana program siaran ini tidak mendidik, jam tayang tidak tepat, adanya muatan pelecehan, kata-kata kasar dan norma kesopanan dan kesusilaan.

b. Program tayangan Kuliner (Trans TV), dimana program siaran ini tidak mendidik, menilai gaya berbusana Farah saat tampil di salah satu episode tayangan kuliner di Trans TV, Ala Chef, dinilai terlalu terbuka karena mengumbar bagian tubuh.

c. Program tayangan reality show Empat Mata (Trans 7), dimana program siaran ini jauh dari nilai edukasi, jam tayang tidak tepat, adanya muatan pelecehan, katakata kasar dan norma kesopanan dan kesusilaan.

d. Juri-juri Indonesian Idol, para juri Indonesian Idol telah merendahkan martabat kemanusiaan berdasarkan identitas gender atau penampilan seseorang.

Informan lain dari ATV Sukabumi Bob DC Pratikno (wawancara tanggal 15 Juni 2012) mengatakan:

"kasus-kasus penyiaran biasanya terjadi dari program-program acara yang tidak mengindahkan kaidahkaidah, etika masyarakat kita; seperti pertunjukkan dangdut yang kadangkadang berlebihan maupun kata-kata dalam lirik lagu yang mengundang/mengarah pada pornografi. Oleh karena itu disarankan agar KPI/KPID lebih serius dalam memonitor program acara di TV swasta nasional”.

Begitu juga informan Liana Meutia dari Kiwari Radio (wawancara tanggal 14 Juni 2012) mengatakan:

"Banyaknya tayangan-tayangan yang mengeskploitasi anak dan mengandung unsur kekerasan pada anak, program yang mengandung SARA dan pelecehan seksual, serta program komedi yang tidak beretika seperti mengejek secara eksplisit".

\section{Komisi Penyiar Indonesia \\ Peran KPI}

Peran KPI menurut beberapa informan sudah sesuai. Hal ini diungkapkan oleh beberapa informan seperti apa yang dikatakan oleh informan I. Thariq Mubarak dari ATV Sukabumi (wawancara tanggal 15 Juni 2012) yang mengatakan:

"KPI Selama ini telah berperan dalam menegur lembaga penyiaran yang melakukan penyiaran yang isinya bertentangan dengan peraturan yang ada, tapi hanya sekedar menegur saja. Tindakan selanjutnya tidak ada. Jadi apabila ada yang melanggar isi penyiaran, terus selanjutnya diteruskan ke pihak mana? Apakah ke Kepolisian? Atau kemana?. Belum jelas".

Hal yang senada juga masih dikemukakan oleh informan dari pemilik Kiwari Radio Pampam Pamungkas (wawancara tanggal 14 Juni 2012) yang mengatakan:

"Peran KPI selama ini sudah berjalan, seperti melakukan teguran kepada pengelola penyiaran yang melanggar aturan yang ada. Namun perannya memonitor belum maksimal sampai menjangkau lokasi penyiaran di daerah. Oleh karena itu diharapkan mampu memaksimalkan monitornya dengan membentuk KPID tingkat Kabupaten/Kota”. 
Selanjutnya pemilik Radio Kiwari Pampam Pamungkas (wawancara tanggal 14 Juni 2012) mengatakan:

"Sejauh ini KPI telah Berperan sesuai dengan UU Penyiaran, karena Undang-undang Penyiaran Nomor 32 Tahun 2002 merupakan dasar utama bagi pembentukan Komisi Penyiaran Indonesia (KPI). Semangatnya adalah pengelolaan sistem penyiaran yang merupakan ranah publik harus dikelola oleh sebuah badan independen yang bebas dari campur tangan pemodal maupun kepentingan kekuasaan. Proses demokratisasi di Indonesia menempatkan publik sebagai pemilik dan pengendali utama ranah penyiaran. Karena frekuensi adalah milik publik dan sifatnya terbatas, maka penggunaannya harus sebesarbesarnya bagi kepentingan publik.".

Sementara ada informan yang berpendapat bahwa peran KPI belum sesuai. Salah satunya informan dari Kiwari Radio Andry Sofiandi (wawancara tanggal 14 Juni 2012) mengatakan:

"Komisi Penyiaran Indonesia (KPI) sebagai 'polisi' penyiaran, memang sudah terbentuk. Tapi action-nya sampai sekarang bisa dikatakan tidak maksimal. Karena masih banyak pelanggaran yang terjadi dalam penyiaran tapi, KPI hanya terlihat menegur dan tidak melakukan tindakan yang tegas. Padahal KPI punya kuasa penuh".

\section{Peran KPI Ke depan}

Selama ini peran KPI menurut sebagian besar informan telah berjalan sesuai dengan peraturan yang ada, namun informan juga menyarankan agar KPI di masa mendatang melakukan perbaikan dan terobosan baru, seperti apa yang dikemukakan oleh informan dari ATV Sukabumi Bob DC Pratikno (wawancara tanggal 15 Juni 2012) sebagai berikut:

"Agar KPI/KPID lebih serius dalam memonitor Program acara di TV swasta
Nasional, dan sebaiknya wewenang yang diberikan ke KPI/KPID lebih luas lagi tidak hanya pada isi siaran saja!"

Pada bagian lain informan Andry Sofiandi dari Kiwari Radio berharap agar KPI di masa mendatang lebih tegas lagi, bisa menindak, jangan hanya menegur lembaga penyiaran yang melakukan pelanggaran. Padahal KPI punya kuasa penuh dalam isi siaran.

Informan Liana Meutia dari Kiwari Radio menyarankan kepada KPI sebagai lembaga Independen harus menjalankan fungsi pelayanan informasi publik yang sehat. Dasar dari fungsi pelayanan informasi yang sehat adalah seperti yang tertuang dalam Undang-undang Penyiaran Nomor 32 Tahun 2002 yaitu Diversity of Content (prinsip keberagaman isi) dan Diversity of Ownership (prinsip keberagaman kepemilikan). Kedua prinsip tersebut menjadi landasan bagi setiap kebijakan yang dirumuskan oleh KP.

\section{Kontruksi Regulasi Penyiaran \\ Dilihat Dari Teks Produk Media}

Bila dilihat dari teks produk media menurut UU Penyiaran sudah tidak sesuai dengan keadaan sekarang. Hal ini dikatakan oleh Andry Sofiandy dari Kiwari Radio (wawancara tanggal 14 Juni 2012). Secara lengkap dia mengatakan: "belum terlaksana, 4 pilar bangsa (Pancasila, UUD, NKRI, Bhineka Tunggal Ika) tidak ditonjolkan. Kepentingan mayoritas dan kepemilikanlah yang dikembangkan. Misalnya: Metro TV dengan Nasdem (Partai Nasional Demokrat). Selanjutnya dia mengatakan:

a. Melihat realita sosial yang ada di bangsa kita, media hanya mampu menampilkan realita saja, tidak mengajak untuk terus meningkatkan moralitas.

b. Kepemilikan media tidak terkendali, ada yang mempunyai 3 televisi dan media massa lainnya dalam satu wilayah (MNC, Bakrie Grup)

c. Informasi yang diberikan belum seimbang, setiap media mempunyai cara pandang sendiri dalam pembawaan berita dan tergantung siapa pemiliknya. 
d. Kebudayaan nasional tampak kabur, karena media memperlihatkan kebudayaan baru dan tidak disaring terlebih dahulu.

Sementara informan Liana Meutia dari Kiwari Radio (wawancara tanggal 14 Juni 2012) mengatakan:

"Banyaknya produk media yang tidak sesuai dengan aturan, contohnya program iklan yang menampilkan halhal yang vulgar dalam busana. Sementara dari Kepemilikan Radio : Banyaknya radio yang tidak memiliki izin resmi dan peralatan yang ilegal. Dalam kapitalisme kepemilikan media saat ini adalah mendominasi hampir seluruh bisnis media Indonesia baik itu media elektronik atau pun media cetak".

Hal lain dikatakan oleh informan I.Thariq Mubarak dari ATV Sukabumi (wawancara tanggal 15 Juni 2012) yang menyatakan:

"bila dilihat dari teks visual produk TV sudah sesuai dengan peraturan, namun masih ada sebagian kecil yang belum sesuai (ini tugas KPI tentang isi siaran)".

\section{Dilihat Dari Media Itu Sendiri}

Bila dilihat dari media itu sendiri menurut informan Andry Sofiandi dari Kiwari Radio (wawancara tanggal 14 Juni 2012) sudah tidak sesuai lagi. Lebih jelasnya dia mengatakan:

"Media penyiaran belum mampu menjalankan asas etika, adil, dan merata, dan tanggung jawab. Sebagai kegiatan komunikasi massa, media televisi/Radio hanya sedikit memberikan fungsi pendidikan, hiburan yang sehat, dan perekat sosial. Di sisi lainnya, televisi digunakan sebagai alat politik, pembentuk opini publik, kepentingan industri. Kebudayaan yang dibawa, tidak tampak merupakan budaya bangsa. Namun kebudayaan modern, yang masuk dari luar dan bisa dikatakan tidak membantu melestarikan budaya bangsa, hanya pada saat hari besar/libur/isu hangat budaya bangsa ditonjolkan".

Pendapat dari informan Liana Meutia (wawancara tanggal 14 Juni 2012) tentang penyiaran bila dilihat dari media itu sendiri, yaitu:

"Semakin meningkatnya peminta untuk memiliki bisnis media, dilihat dari semakin banyaknya radio baru atau TV lokal di kota-kota besar yang menyebar ke kota-kota kecil".

\section{Dilihat Dari Institusi Sosial Dalam Pasar}

Menurut informan Andry Sofiandi media penyiaran lebih banyak menayangkan komersialnya ketimbang lembaga sosial. Sementara menurut informan Liana Meutia, terjadi peningkatan kerja sama antara institusi sosial dan media.

Pendapat kedua informan itu beralasan karena saat ini memang benar hampir semua penayangan acara baik di radio atau di TV lebih banyak komersialnya dari pada segi sosialnya. Namun disamping itu masih ada sebagian kecil acara yang menayangkan sosialnya seperti acara-acara reality show yang menggugah hati nurani.

\section{Regulasi Di Era Konvergensi}

Dilihat Dari TIK Yang Berkembang

Pendapat informan Andry Sofiandi dari Kiwari Radio (Wawancara tanggal 14 Juni 2012) tentang regulasi di era konvergensi bila dilihat dari TIK yang berkembang, sebagai berikut:

"Regulasi tentang penyiaran harus lebih disempurnakan agar tidak terjadi tumpang tindih. Saat ini konvergensi teknologi informasi, telekomunikasi, dan juga penyiaran telah menjadi fenomena sehari-hari yang bisa disaksikan masyarakat luas. Teknologi-teknologi yang sebelumnya terpisah semakin terintegrasi menjadi satu. Banyak anggota masyarakat menggunakan 
ponsel berkamera; mengakses data melalui jaringan nirkabel atau dengan smartphone ketika mereka masih di tengah perjalanan menuju kantor atau klien mereka; dan menyaksikan video, atau bahkan TV, melalui ponsel. Konvergensi teknologi ini dalam berbagai bentuknya telah dimanfaatkan oleh masyarakat kita".

Pada bagian lain dia mengatakan:

"Dampak konvergensi secara sosial juga sudah dirasakan, baik yang positif maupun negatif. Dengan modal ponsel berkamera masyarakat bisa turut menjadi penyebar berita mulai dari menyampaikan berita bencana alam untuk menggalang bantuan, sampai menyebarkan aktivitas pribadi yang bisa menghancurkan karir politik seseorang. Kemudahan berkomunikasi baik melalui jaringan telekomunikasi dan internet telah berhasil memulihkan hubungan persahabatan dan kekeluargaan yang telah lama tidak tersambung. Fenomena blog juga memungkinkan tiap orang untuk menjadi sumber berita".

Dengan demikian, regulasi di era konvergensi bila dilihat dari perkembangan TIK pada saat ini sangat diperlukan sesuai dengan perkembangan TIK itu sendiri.

\section{Dilihat Dari Beberapa Peraturan Yang Sejenis}

Pada saat ini peraturan penyiaran berdasarkan UU penyiaran bila dilihat dengan peraturan yang sejenis, dikatakan informan Andry Sofiandi dari Radio Kiwari (wawancara tanggal 14 Juni 2012):

"Masih ada beberapa poin yang harus lebih disesuaikan dengan perkembangan teknologi informasi dan peraturanperaturan yang dinilai masih tumpang tindih dan dinilai masih terpisah satu sama lain harus lebih disempurnakan”.
Begitu juga dengan pendapat informan-informan lainnya mengatakan bahwa dengan peraturan yang sejenis masih terlihat adanya kesamaan, dan seolah tumpang tindih. Namun masih terlihat juga perbedannya. Jadi sebaiknya UU Penyiaran tetap dalam undang-undang tersendiri, namun ada perbaikan di beberapa pasal yang dianggap sudah tidak sesuai lagi dengan perkembangan zaman.

Harapan Regulasi yang Ideal di Masa akan Datang.

Regulasi/kebijakan penyiaran yang ideal diusulkan oleh beberapa informan, seperti informan Pampam Pamungkas Andry Sofiandi dari Kiwari Radio dan I. Thoriq dari ATV Sukabumi, mereka menyarankan:

1. UU Penyiaran No 32 tahun 2002 perlu direvisi, tidak perlu digabung dengan UU lain.

2. Kewenangan penyiaran diberikan kepada daerah provinsi sesuai dengan otonomi daerah (jangan sentralistik)

3. Izin penyiaran masih boleh diberikan oleh pemerintah, namun cukup oleh pemerintah Daerah

4. Perlu dibentuk KPID tingkat kabupaten/kota, agar bisa memonitor siaran sampai ke pelosok-pelosok.

5. Pengelola media hendaknya lebih berpihak kepada penonton

6. Konten penyiaran yang bertanggung jawab, memberikan pendidikan dan pencerahan kepada masyarakat, terutama anak-anak, sehingga anak-anak kita aman ketika menonton siaran TV.

\section{PEMBAHASAN}

\section{Konstruksi Regulasi Penyiaran}

Keseluruhan tarik-menarik penilaian terhadap regulasi Penyiaran (UU No. 32 Tahun 2002) jika dianalisis dengan menggunakan teori social construction of reality dari Berger dan Lucmann (1966) pada hakikatnya juga mencerminkan perbedaan para pihak dalam mengonstruksi UU 
Penyiaran sebagai sebuah realita.

Dalam penelitian ini terlihat bahwa dalam mengonstruksi regulasi penyiaran berdasarkan UU 32/2002, informan memberikan pendapatnya yang satu sama lainnya ada perbedaan meskipun pada banyak hal ada persamaan pula. Ini tergantung dari realitas keseharian informan di lapangan yang selalu bergelut dengan keberlangsungan penyiaran baik melalui televisi maupun radio.

Informan yang kesehariannya bergelut di radio mengkonstruksi regulasi penyiaran yang selama ini berlaku ternyata sudah tidak sesuai lagi dengan perkembangan di era informasi ini. Sepeti apa yang dikemukakan oleh informan Liana Meulina dari Kiwari Radio (wawancara tanggal 14 Juni 2012) yang mengatakan bahwa :

"Regulasi/kebijakan tentang penyiaran yang ada sudah tidak sesuai, karena kemajuan teknologi penyiaran yang berkembang dengan cepat menyebabkan landasan hukum pembinaan dan pengembangan yang ada selama ini sudah tidak memadai lagi, dan perkembangan teknologi komunikasi dan informasi telah melahirkan masyarakat informasi yang makin besar tuntutannya akan hak untuk mengetahui dan hak untuk mendapatkan informasi."

Namun informan yang sehari-harinya bergelut di TV, seperti informan Manager Program ATV Sukabumi, Bob DC Pratikno berpendapat regulasi/kebijakan UU penyiaran yang telah ada selama ini menurutnya masih sesuai dengan perkembangan teknologi informasi, mengingat dalam regulasi itu sudah memuat peraturan yang mengikat.

Seperti telah dikemukakan sebelumnya bahwa proses mengonstruksi berlangsung melalui interaksi sosial yang dialektis dari tiga bentuk realitas, yakni symbolic reality, objective reality, dan subjective reality. yang berlangsung dalam suatu proses dengan tiga simultan; eksternalisasi, objektivasi, dan internalisasi.

Symbolic Reality (teks Produk Industri Media, Representsi Pasar, Kapitalisme)

Dalam symbolic reality, yang termasuk di dalamnya tentang teks produk media, informan Liana Meutia dari Radio Kiwari (wawancara tanggal 14 Juni 2012) mengatakan:

"Banyaknya produk media yang tidak sesuai dengan aturan, contohnya program iklan yang menampilkan halhal yang vulgar dalam busana. Sementara dari Kepemilikan Radio: Banyaknya radio yang tidak memiliki izin resmi dan peralatan yang ilegal. Dalam kapitalisme kepemilikan media saat ini adalah mendominasi hampir seluruh bisnis media Indonesia baik itu media elektronik atau pun media cetak".

Hal lain dikatakan oleh informan I.Thariq Mubarak dari ATV Sukabumi (wawancara tanggal 15 Juni 2012) yang menyatakan:

"bila dilihat dari teks visual produk TV sudah sesuai dengan peraturan, namun masih ada sebagian kecil yang belum sesuai (ini tugas KPI tentang isi siaran)".

Dalam hal pasar dan kapitalisme media, sekarang ini telah terjadi monopoli media oleh beberapa grup pemilik media yang menguasai pasar, baik media radio maupun televisi seperti terlihat pada gambar 2 .

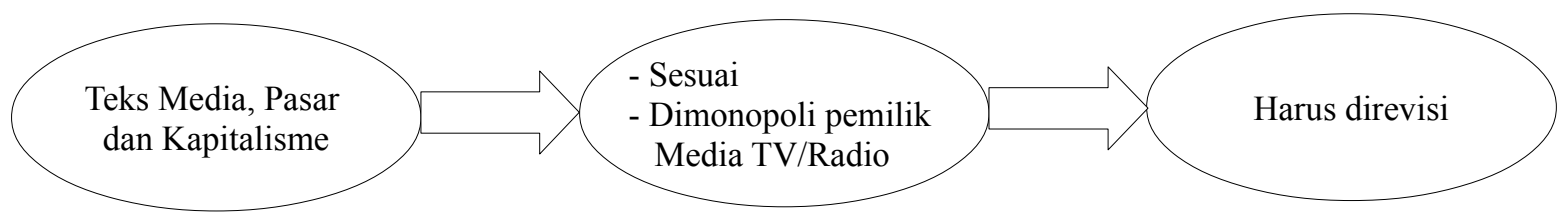

Sumber : hasil penelitian 2012

\section{Gambar 2}

Model Teks Produk Media, Pasar, dan Kapitalisme 


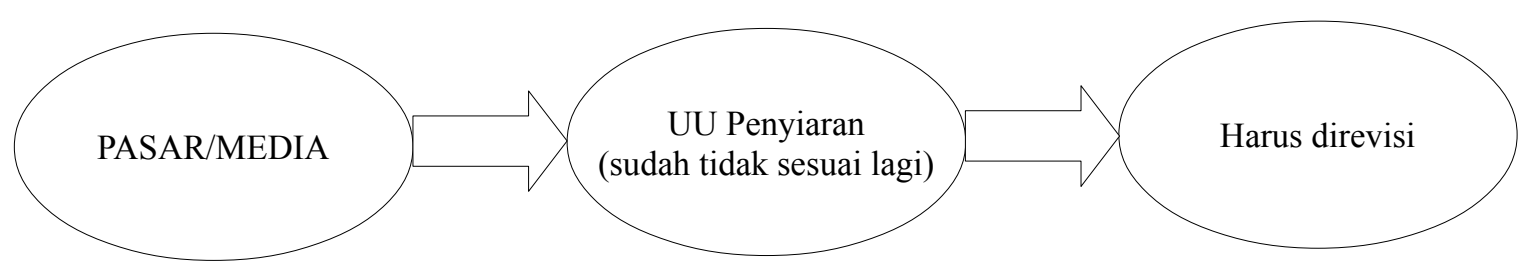

Sumber : hasil penelitian 2012

\section{Gambar 3}

\section{Model Pasar Dan Media Penyiaran Dengan Peraturan Yang Ada}

\section{Subjective Reality (media, pasar, dll)}

Bila dilihat dari media itu sendiri menurut informan Andry Sofiandi (wawancara tanggal 14 Juni 2012) sudah tidak sesuai lagi. Lebih jelasnya dia mengatakan:

"Media penyiaran belum mampu menjalankan asas etika, adil, merata, dan tanggung jawab. Sebagai kegiatan komunikasi massa, media televisi/Radio hanya sedikit memberikan fungsi pendidikan, hiburan yang sehat, dan perekat sosial. Di sisi lainnya, televisi digunakan sebagai alat politik, pembentuk opini publik, kepentingan industri. Kebudayaan yang dibawa, tidak tampak merupakan budaya bangsa. Namun kebudayaan modern, yang masuk dari luar dan bisa dikatakan tidak membantu melestarikan budaya bangsa, "hanya pada saat hari besar/libur/isu hangat budaya bangsa ditonjolkan."

Pendapat dari informan Liana Meutia (wawancara tanggal 14 Juni 2012) tentang penyiaran bila dilihat dari media itu sendiri, yaitu:

"Semakin meningkatnya peminta untuk memiliki bisnis media, dilihat dari semakin banyaknya radio baru atau TV lokal di kota-kota besar yang menyebar ke kota-kota kecil".

Bila dilihat dari pasar, saat ini pasar cenderung berbanding terbalik dengan peraturan yang telah ada, di mana peraturan atau undang-undang sudah tidak sesuai lagi dengan perkembangan yang ada. Apalagi perkembangan teknologi informasi saat ini begitu cepat, sehingga pasal-pasal dalam peraturan mengenai penyiaran banyak yang tidak sesuai lagi seperti terlihat dari gambar 3 .

\section{Objective Reality (berbagai Institusi Sosial Dalam Pasar)}

Menurut informan Andry Sofiandi media penyiaran lebih banyak menayangkan komersialnya ketimbang lembaga sosial. Sementara menurut informan Liana Meutia, terjadi peningkatan kerja sama antara institusi sosial dan media.

Itulah yang terjadi saat ini, di satu sisi media sangat antusias untuk mendapatkan keuntungan yang sebesar-besarnya, namun di sisi lain masih ada segelintir acara yang menayangkan reality show tentang realitas kehidupan yang dapat menyentuh hati nurani pemirsa. Tidak sedikit pemirsa yang tergerak hatinya untuk membantu sesama yang memerlukan bantuan materi melalui dompet duafa atau langsung ke korban.

Penulis sependapat dengan apa yang dikatakan informan Liana Meutia dari Kiwari Radio, karena pada saat ini telah terjadi kerja sama antara institusi sosial dengan media. Seperti dalam acara Kick Andy Metro TV, sering ditayangkan antara media dengan lembaga sosial yang menjadi insprirasi bagi pemirsa. Secara sederhana akan disajikan dalam model seperti pada gambar 4 .

Dari beberapa uraian dan gambar sebelumnya dapatlah di tampilkan gambar secara keseluruhan tentang suatu model regulasi penyiaran di era konvergensi. Model tersebut akan disajikan dalam model seperti pada gambar 5 . 


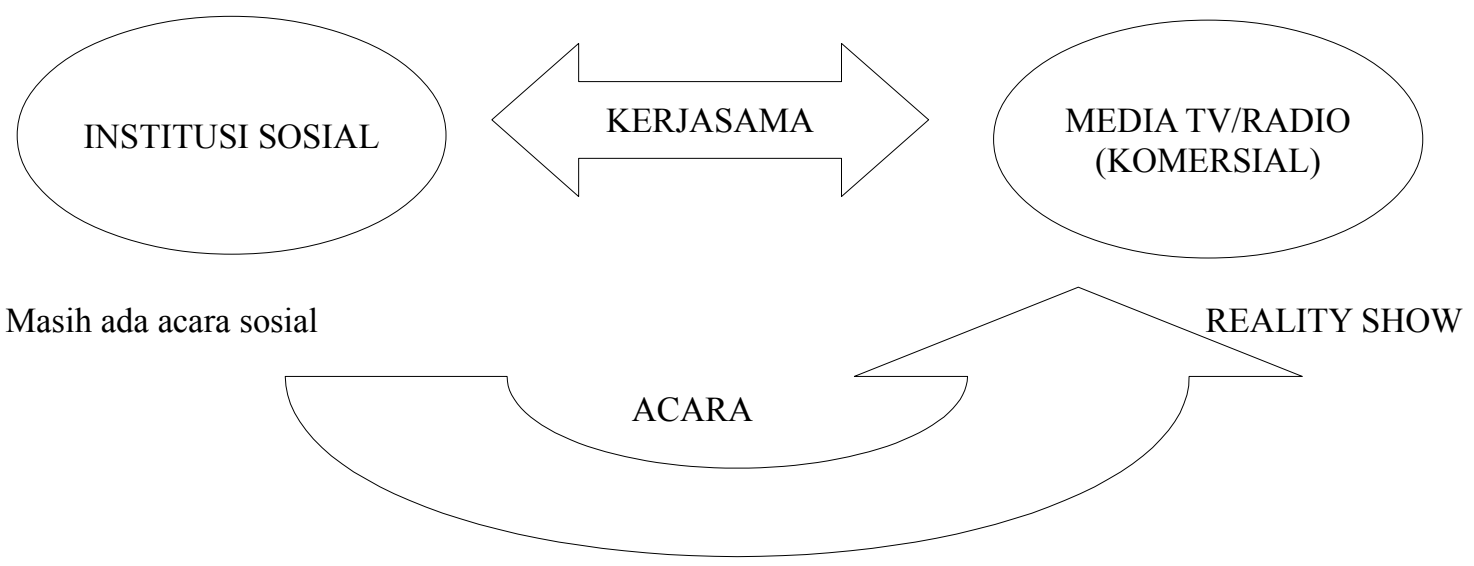

Sumber : hasil penelitian 2012

Gambar 4

Model Media Pasar Dengan Institusi Sosial

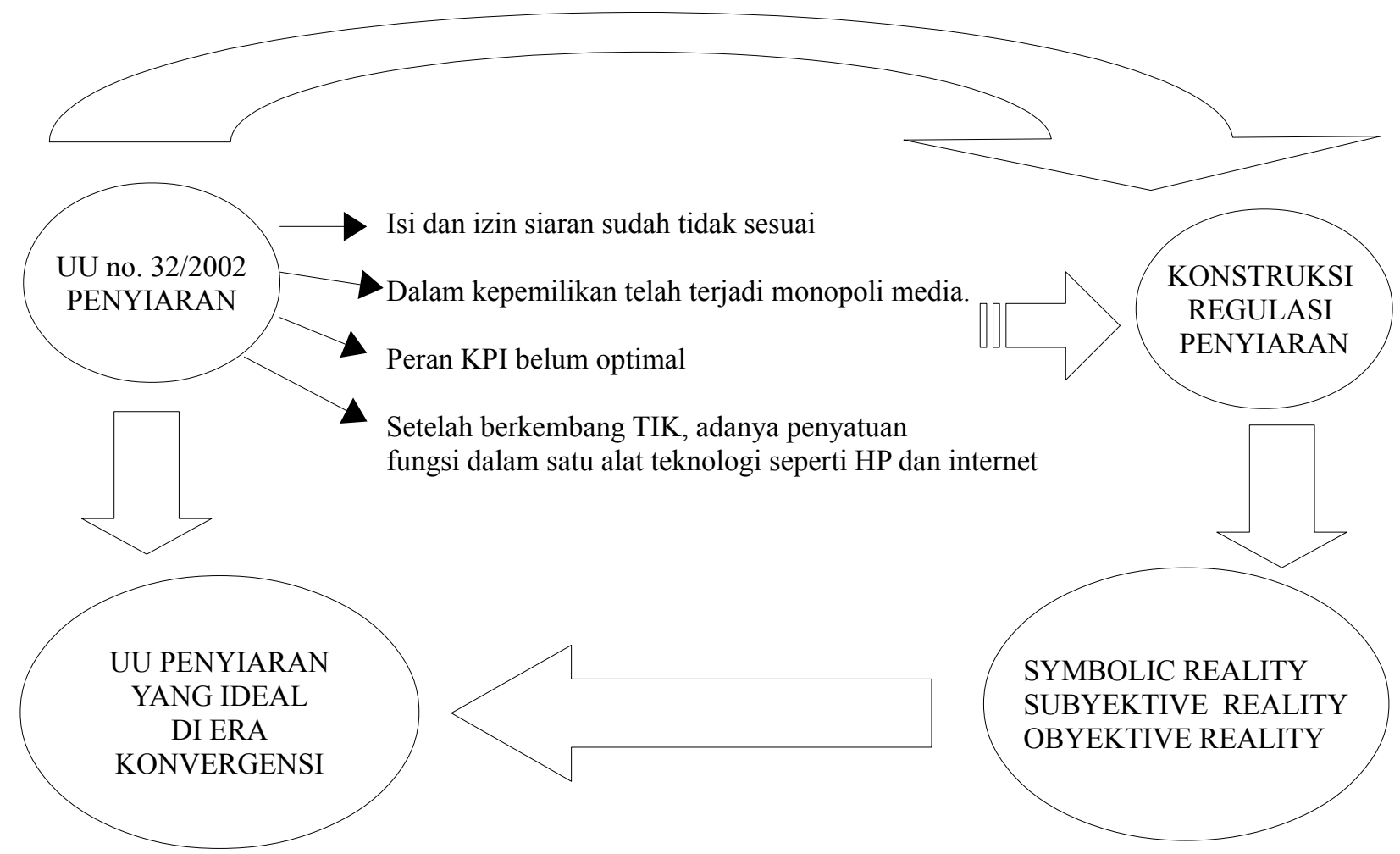

Sumber : hasil penelitian 2012

Gambar 5

Model Regulasi Penyiaran Di Era Konvergensi 


\section{PENUTUP}

\section{Simpulan}

Konstruksi regulasi mengenai isi siaran dan izin penyelenggaraan siaran berdasarkan UU Penyiaran, sebagian besar pasal-pasalnya sudah tidak sesuai lagi dengan perkembangan di era informasi ini.

Konstruksi regulasi mengenai kepemilikan lembaga penyiaran berdasarkan UU Penyiaran, sudah tidak sesuai lagi dengan kenyataan yang ada di lapangan. Dimana saat ini telah terjadi monopoli kepemilikan lembaga penyiaran.

Peran KPI apabila ada pelanggaran terhadap UU penyiaran belum optimal, karena hanya sebatas memberikan teguran, jarang memberikan sanksi. Padahal kewenangan KPI cukup luas, mulai menyusun standar program siaran, mengawasi isi siaran, memberikan sanksi, dan ikut membangun iklim persaingan yang sehat antar lembaga penyiaran dan industri terkait.

Kosntruksi regulasi penyiaran setelah berkembangnya TIK di era konvergensi telah terjadi, di mana teknologi-teknologi yang sebelumnya terpisah semakin terintegrasi menjadi satu.

\section{Saran}

Diharapkan peraturan tentang Penyiaran (UU NO 32/2002) segera diperbaiki terutama mengenai isi siaran, izin penyelenggaraan siaran, dan kepemilikan lembaga penyiaran. UU tersebut tidak perlu digabung dengan UU lainnya hanya perlu direvisi.

Peran KPI harus dioptimalkan supaya bisa mengikuti perkembangan zaman dan menyeimbangkan antara kepentingan bisnis dan peraturan yang berlaku di KPI sehingga tidak terjadi penyimpangan peraturan. Dilakukannya sosialisasi mengenai perkembangan teknologi di dunia media dan sosialisasi peraturan KPI pada pelaku bisnis media. Kalau memungkinkan diharapkan dibentuk KPID tingkat Kabupaten/Kota.

Konvergensi teknologi telah terjadi di dalam berbagai bentuk dan telah dimanfaatkan oleh masyarakat kita, seperti HP dan internet. Agar pengguna dapat memanfatkan teknologi dengan sebaik-baiknya dengan menghindari segi negatifnya.

Agar regulasi penyiaran sesuai dengan yang diharapkan (ideal), sebaiknya apabila ada rencana perubahan terhadap UU, perlu disosialisasikan terlebih dulu oleh yang berkepentingan/instansi-instansi kepada daerah-daerah, agar daerah bisa memberikan masukan yang berarti bagi kesempurnaan UU tersebut.

\section{DAFTAR PUSTAKA}

Budhijanto, Danrivanto. (2010). Hukum, Telekomunikasi, Penyiaran, \& teknologi Informasi, Regulasi \& Konvergensi. Bandung: Refika Aditama.

Bungin, Burhan. (2008). Sosiologi Komunikasi, (Teori, Paradigma, dan Diskursus Teknologi Komunikasi di Masyarakat). Jakarta: Kencana Predana Media Group.

Berger, Peter L and Luckmann. Thomas. (1990).Tafsir Sosial Atas Kenyataan. Jakarta:LP3ES.

Hidayat, Deddy N. (2003), Konstruksi Sosial Industri Penyiaran. Jakarta: Pascasarjana Ilmu Komunikasi UI.

J. Severin, Werner - W. Tankard, James, Jr.. (2007). Teori Komunikasi, (Sejarah, Metode, dan Terapan di Dalam Media Massa). Jakarta: Kencana Predana Media Group.

Mufid, Muhamad. (2010). Komunikasi Dan regulasi Penyiaran. Jakarta: Kencana Predana Media Group.

Sugiyono. (2008). Memahami Penelitian Kualitatif. Bandung: Penerbit CV. Alfabeta.

Uchjana Onong Effendi. (2003). Ilmu, Teori dan Filsafat Komunikasi. Bandung: Penerbit PT. Citra Aditya Bakti.

\section{Jurnal/Kajian Komunikasi:}

Haryati.(2008). Media Baru, Pemerataan Akses Dan Perlindungan Konsumen. Dalam : OBSERVASI (Kajian Komunikasi Dan Informasi) Vol. 6, No. 
2. Mengejar Tren Konvergensi Media. Hal. 48. Bandung : kerjasama BPPKI Bandung, Badan Litbang SDM Depkominfo, dengan Penerbit Simbiosa Rekatama Media.

Sahala, Sahat Tua Saragih. (2004). Lulusan Subprogram Studi Penyiaran, Bisa Apa Sih?. Dalam Jurnal Komunikasi dan Informasi (Journal of Communication and Information). DUNIA KOMUNIKASI, DUNIA KITA. Hal. 155. Bandung: FIKOM UNPAD.

\section{Internet:}

Artikel Layu Sebelum Berkembang: Masa Awal Kelahiran KPI, tersedia dalam $<$ http://chatatancalonwartawan.wordpress.com/tag/kronologis-proses-uji-materi-uu-no-32-tahun-2002/>, diakses $8 / 01 / 2012$.

Hamdi, Mujtaba. (2011). Konvergensi
Industri Media Dan Hak Publik Presentation Tran script, Perkumpulan Media Link 27.12.2011 tersedia dalam $<$ http://www.slideshare.net/satudunia/ko nvergensi-industri-media-dan-hakpublik, selasa $>$, diakses 24/1/2012

Mukhlisin. tersedia dalam $<$ http://icrp-online.org/042012/post-1849.html> diakses , 5/6/2012.

http://bahankuliahikomunand.files.wordpress.com/2011/06/makalah-hep.docx, 5/6/2012.

Makalah, Konstitusi Konsep Dasar Konstitusi. Tersedia dalam <www.fileskripsi.com/2011/01/konstitusi-konsep-dasarkonstitusi.html,> Diakses 8/6/2012.

Shinta Yunitasari, tersedia dalam $<$ http://Shinsishinsi.blogspot.com/2012/ 03/pengertian-hukum.html>, diakses 8/6/2012. 